Mindfulness in Context: A Historical Discourse Analysis

Jessie Sun

University of Melbourne

This is an author's copy of an article published by Taylor \& Francis:

Sun, J. (2014). Mindfulness in context: A historical discourse analysis. Contemporary Buddhism, 15(2), 394-415. http://dx.doi.org/10.1080/14639947.2014.978088

Please email the author at jesssun@icloud.com for a copy of the typeset, paginated PDF. 


\begin{abstract}
'Mindfulness' has become a buzzword, yet its meaning and origins have received relatively little critical consideration. This article places the current 'mindfulness movement' in context, examining the evolving discourse surrounding the concept of mindfulness. Through the first systematic etymology of the term, drawing from old Western and Buddhist writings, contemporary psychology and popular media, it is established that the contemporary understanding of mindfulness has been substantially simplified and divorced from its origins. However, quantitative data suggests that this manoeuvre was essential for the mainstreaming of the concept. Moreover, the resulting momentum has stimulated a new and dynamic discourse about the relationship between 'secular' mindfulness and Buddhism, sparking questions about 'McMindfulness', 'stealth' Buddhism and cultural imperialism. Therefore, this article argues that the recontextualisation of mindfulness created the scaffolding that supported the emergence of a deeper and more meaningful conversation about its implications for Buddhism and society that we see today.
\end{abstract}




\section{Mindfulness in Context: A Historical Discourse Analysis}

Stressed out? Want to improve your focus and get in the zone? Boost your productivity and profits? Improve your GRE scores? Have a better sex life? Sleep better at night? You can bust your stress in just 25 minutes a day or even do it on-the-go. It's 'Buddhist-inspired' but definitely not 'Buddhist', so anyone can make use of the 'hottest meditative tool'.

'Mindfulness', at the turn of the twenty-first century, has become a buzzword that has garnered an explosion of interest and enthusiasm. Having now permeated the discourse of several societal institutions, including medicine, psychology, the corporate world, schools, politics, the military and mainstream media, proponents have declared the beginnings of a ‘mindfulness revolution' (Boyce 2011).

In the midst of this hype, however, far less attention has been given to the meaning and origins of the concept than what it can do for you. Few people outside of Buddhist communities or scholarship understand 'mindfulness' to be anything other than what it is popularly portrayed as: a helpful, secular technique that involves paying attention to the present moment in a non-judgemental way (Kabat-Zinn 1994, 4). However, a critical lens and thorough historical study is required to gain a fuller understanding of the meanings it has held and the implications of its newfound popularity and applications.

First, through a detailed etymology, it is established that the meaning of mindfulness has been substantially simplified and divorced from its origins in this new discourse. However, I then suggest that this manoeuvre represents a skilful recontextualisation of mindfulness that was essential for the mainstreaming of the concept. Finally, I propose that the resulting enthusiasm and momentum has, in turn, stimulated a new and dynamic discourse about the relationship between Buddhism and 'secular' mindfulness. Therefore, I 
argue that the recontextualisation of mindfulness created the scaffolding that supported the emergence of a deeper and more meaningful conversation about its implications for Buddhism and society that we see today.

\section{The oversimplification of mindfulness}

Mindfulness has largely been portrayed in a very simplistic and taken-for-granted manner in mainstream media and the psychological literature. However, the following etymology illustrates the depth and richness of the term across history, and how its meaning has evolved to its present-day understanding.

\section{'Western' mindfulness}

'Mindfulness' existed in the English language long before it became associated with Buddhism and meditation. 'Mind' emerged in the late twelfth century, and has had meanings relating to memory, thought, intention, perceiving or noticing, care, and objection ('mind', Online Etymology Dictionary; 'mind', Oxford English Dictionary Online, 3rd ed.). 'Mindful', or 'characterised by mind', emerged in the mid-fourteenth century. 'Mindful' has been used in senses of remembrance, being thoughtful or full of care, being conscious or aware, and intending to do something ('mindful', Oxford English Dictionary Online, 3rd ed.). Finally, 'mindfulness', or the 'state or quality of being mindful', emerged in 1530, when John Palsgrave translated the French term pensée (Palsgrave 1530, 245). It has denoted memory; attention, alertness, watchfulness; intention, purpose; and thoughtfulness, regard or care ('mindfulness', Oxford English Dictionary Online, 3rd ed.; Johnson [1755] 1838, 76; Bailey and Harwood 1782; Perry and Johnson 1805; Webster 1914, 365). It is more illuminating, however, to examine the discourse surrounding the concept, to reveal the deeper implications of these definitions. 
In early usages, mindfulness was seen as important in supporting Christian ways of being, through maintaining a 'habitual' or 'continual' mindfulness of God's presence (Alfton 1704, 274; Grymeston [1604] 1992; O. 1737, 335; Sutton 1630, 259-260). This is because thinking frequently of God, keeping him in mind, and being aware of his presence helps to prevent $\sin ($ Henry 1790, 734) and to increase devotion and spiritual growth (Faber 1855, 467; O. 1737, 335).

Mindfulness was also closely intertwined with gratitude. In order to be thankful, one must remember, or have mindfulness of the good that others have done (Ambrose 1652, 508; Hoyt 1894, 358; Shaw 1907, 362). Similarly, those on the receiving end of another's mindfulness appreciate the consideration and regard that has been shown to them (Bronte 1857, 113; Nisbet 1856, 385).

Finally, mindfulness was often paired with or described in terms that conveyed an affective quality of love, kindness, care and consideration for others. Descriptions such as an 'affectionate mindfulness' (Raleigh 1883, 201), a 'mother's mindfulness' (Delta 1830, 389) and a 'considerate kindness and mindfulness' (Roesart 1859, 60) elevated mindfulness to the level of a virtue (Berry 1969, 25; Cicero 1841, 47) and a mark of good character (Bronte 1857, 113; Hamilton 1850, 270).

'Western' mindfulness therefore supported religious life, and had a distinct moral and affective quality with its largely other-oriented focus. It was therefore seen as a trait or tendency worth cultivating. However, this usage of mindfulness is now largely obsolete ('mindfulness', Oxford English Dictionary Online, 3rd ed.).

\section{'Buddhist'mindfulness}

It was only in 1881 that mindfulness first became associated with Buddhism, but this soon overtook the older Western usage of mindfulness. The Pali textual scholar T. W. Rhys 
Davids was responsible for this shift in the meaning of the word, being the first to translate the Pali word sati as 'mindfulness' in his translation of the Mahāparinibbāna Sutta (Rhys Davids 1881).

Mindfulness was not an obvious translation of sati, which Rhys Davids [1890] 2001, 107) described as 'one of the most difficult words . . . in the whole Buddhist system . . . to translate'. Rhys Davids $(1910,322)$ noted that while etymologically, smrti, the Sanskrit equivalent of sati, normally means memory and remembrance, at the rise of Buddhism a new connotation was attached to the word that gave a new meaning to it, making 'memory' an inadequate and misleading translation. The Buddha inevitably had to draw on the available vocabulary when devising a terminology to communicate his teachings (Bodhi 2011, 22). However, Rhys Davids $(1910,322)$ suggests that sati became the 'memory, recollection, calling-to-mind, being-aware-of, certain specified facts', most importantly, the impermanence of all phenomena, and the repeated application of this awareness to every experience to support ethical conduct.

This description echoes the religious and moral connotations of 'Western' mindfulness. Yet, previous scholars had not considered this term, translating sati as ‘conscience' (Hardy 1850, 442) and 'meditation' (Gogerly 1845, 23-25). Rhys Davids himself had shown some uncertainty, using 'mental activity' and 'thought' along with 'mindfulness' in $1881(9,14,63)$. However, 'mindfulness' soon became established as the only possible English translation of sati, with few exceptions. Therefore, Rhys David's translation was an important development for the future of the use of the word 'mindfulness' in the English language, as he systematised and clarified previous translational uncertainties, after other terms had been tried and found inadequate. 
In investigating in more detail what sati, now 'mindfulness', meant in a Buddhist context, it is important to note that Buddhism is a plural tradition, and therefore that conceptions and practices of mindfulness also differ between traditions (Dreyfus 2011, 42). Nevertheless, it is instructive to take the Pali Canon of early Buddhism as a starting point, although we should not see this as the normative nor definitive 'Buddhist view of mindfulness'.

Part of the reason why sati may have been such a difficult term to translate may lie in its ambiguous usages in the Canon, as well as the lack of a clear, formal definition. As Bodhi $(2011,23)$ explains, the oral transmission of Buddhist scriptures required that the main points of the Buddha's discourses be compressed into simple, repetitive formulas to aid memorisation. Therefore, instead of clear explanations of what sati means, the texts only provide operational demonstrations that indicate how it functions in Buddhist psychology and meditation practice (Bodhi 2011, 23).

The opening of the Satipatthana Sutta, the 'Discourse on the Establishment of Mindfulness', illustrates the central role of mindfulness practice in the Buddhist path: Monks, this is the one-way path for the purification of beings, for the overcoming of sorrow and lamentation, for the passing away of pain and displeasure, for the achievement of the method, for the realization of nibbana, that is, the four establishments of mindfulness. (Dīgha Nikāya, 22.1, as quoted in Bodhi 2011, 21)

The four establishments of mindfulness, the satipatthānas, are described in a recurring passage: 
Here, a monk dwells contemplating the body in the body . . . feelings in feelings . . . mind in mind ... phenomena in phenomena, ardent, clearly comprehending, mindful, having removed covetousness and displeasure in regard to the world. (Dìgha Nikāya, 22.1, as quoted in Bodhi 2011, 21)

Mindfulness therefore involves contemplating the four domains of the body, feelings, states of mind, and experiential phenomena (dhamma), and the purpose of the practice is the extinction of suffering and the attainment of nirvana. In various contexts, the recurring passage is followed by 'This is called right mindfulness' (sammāa-sati; Dīgha Nikāya, 22.1, as quoted in Bodhi 2011, 20), 'This is called the faculty of mindfulness' (satindriya; Samyutta Nikāya, V 197, as quoted in Bodhi 2011,24), and 'on that occasion the monk arouses, develops, and fulfills the enlightenment factor of mindfulness' (satisambojjhangga; Samyutta Nikāya, V 67, as quoted in Bodhi 2011, 24). This underscores the connection between mindfulness and meditation practice. As well as this, right mindfulness forms an integral part of the eightfold noble path, in which it also ensures the correct practice of all the other path factors, imbuing the concept with an ethical function (Bodhi 2011, 27).

Bodhi $(2011,21)$ further interprets the phrase, 'ardent, clearly comprehend- ing, mindful', as indicating that the 'establishment of mindfulness' involves a constellation of mental factors that work in tandem. 'Ardent' $(\bar{a} t \bar{a} p \bar{\imath})$ implies vitality and the strength to engage in the practice, 'mindfulness' (sati) is the element of watchfulness and lucid awareness, and 'clearly comprehending' (sampajāno) involves the interpretation of what has arisen. While mindfulness prevails initially, clear comprehension becomes increasingly important as the practice advances, allowing it to evolve into insight (vipassanā), which is an 
understanding of impermanence (anicca), unsatisfactoriness (dukkha) and non-self (anattā), that eventually allows wisdom (pañña) to develop (Bodhi 2011, 22; Dreyfus 2011, 51).

Complicating this picture, however, other recurrent descriptions of mindfulness appeal back to the older memory-related connotations of sati:

And what, monks, is the faculty of mindfulness? Here, the noble disciple is mindful, possessing supreme mindfulness and alertness, one who remembers and recollects what was done and said long ago. This is called the faculty of mindfulness. (Samyutta Nikāya, V 197, as quoted in Bodhi 2011, 24)

[T]he monk recollects that Dhamma and thinks it over. By doing so, on that occasion the monk arouses, develops, and fulfills the enlightenment factor of mindfulness. (Samyutta Nikāya, V 200, as quoted in Bodhi 2011, 24)

Bodhi (2011, 25-26) provides one interpretation to reconcile these ambivalent usages. He suggests that establishing mindfulness through the satipatțhānas involves adopting a particular stance towards one's present experience that vividly establishes the presence of an object. Mindfulness can therefore be understood as 'lucid awareness', either of a vividly presented memory or a bodily process or mental event in the present. This mental pose can also be applied to conceptual objects, such as the Buddha, the Dhamma, the Sangha, Virtue (sīlānussati), generosity (cāgānussati), death (maraìānussati) and peace (upasamānussati) (Shaw 2008, 110). The unifying factor is that they each bring their objective domain vividly before the mind (Bodhi 2011, 26). 
Therefore, at least in early Buddhist scriptures, sati had multiple usages. It carried a profound ethical connotation as right mindfulness, and was developed and exercised through the meditative practice of the four establishments of mindfulness. Within the context of satipațthāna practice, however, sati also referred to a specific mental factor, characterised by lucid awareness, which needed to be combined with several other mental factors for the practice to develop. Finally, this lucid awareness could pertain to either conceptual or nonconceptual objects, in the present or held in memory.

\section{Mindfulness as 'bare attention'}

However, mindfulness later became associated with ‘bare attention', first coined by the German monk, Ven. Nyanaponika Thera. Nyanaponika $(1962,62)$ wrote that mindfulness 'applies preeminently to the attitude and practice of bare attention in a purely receptive state of mind' and 'is kept to a bare registering of the facts observed, without reacting them to them by ... self-reference (like, dislike, etc.), judgement or reflection' $(1962,30)$.

Nyanaponika therefore emphasised an open, receptive and non-judgemental mindset in characterising mindfulness as bare attention.

Similarly, Ven. Henepola Gunaratana, in his popular book, Mindfulness in Plain English, identifies mindfulness as the 'fleeting instant of pure awareness just before you conceptualize the thing, before you identify it' (Gunaratana 2002, 138). In emphasising this non-conceptual, non-elaborative quality of mindfulness, Gunaratana explicitly equates mindfulness with bare attention:

Mindfulness is non-conceptual awareness. Another English term for sati is 'bare attention.' It is not thinking. It does not get involved with thought or concepts ... It is, 
rather, the direct and immediate experiencing of whatever is happening, without the medium of thought. (Gunaratana 2002, 140)

Other scholars (Bodhi 2011, 30; Gethin 2011, 266-277), however, have noted that this description of mindfulness merges its meaning with another technical term in Buddhist psychology, manasikāra, translated as 'attention'. This is an automatic function that orients one's attention to an object as soon as it arises at the 'mind door'. Mindfulness, however, allows for sustained attention on the object to make it appear vividly, and needs to be cultivated through deliberative effort (Bodhi 2011, 30).

Despite the disparity between the characterisation of mindfulness as 'bare attention' and its descriptions in early Buddhist scriptures, the non-conceptual, non-judgemental and non-elaborative features of bare attention became influential ideas in the development of 'secular' mindfulness.

\section{'Secular' mindfulness}

How did both the Christian linking of mindfulness with attention to God and caring for others and the rich variety of meanings in Buddhism lead to the secular and - to my mind —rather impoverished use of the word in contemporary discourse? As I will argue in the following sections, 'secular' mindfulness is the only usage that has made it into the mainstream, and may be precisely due to the way it has been defined and portrayed.

'Secular' mindfulness was popularised by Jon Kabat-Zinn's pioneering work in introducing mindfulness to medical settings through his Mindfulness-Based Stress Reduction (MBSR) programme (Kabat-Zinn 1982). However, mindfulness in the 'Kabat-Zinn tradition' (Seager 2012, 212) did not emerge out of a vacuum. Having admired Nyanaponika's writings (Kabat-Zinn 2011, 291), 'bare attention' was particularly influential 
in shaping Kabat-Zinn's conceptualisation of mindfulness. This influence can be seen in Kabat-Zinn's first clinical paper on mindfulness, where he emphasised the feature of 'detached self-observation' of momentary experience, which would achieve a state of 'bare attention' and 'choiceless awareness' (Kabat-Zinn 1982, 34).

Following this, Kabat-Zinn later provided an influential operational definition of mindfulness: 'paying attention in a particular way: on purpose, in the present moment, and non-judgementally' (Kabat-Zinn 1994, 4). This definition provided the basis for further refinements, theoretical models, and measurements of mindfulness in the emerging psychological literature. Ranging from one to five components, these understandings commonly emphasise present orientation (Bishop et al. 2004; Brown and Ryan 2003; Lau et al. 2006), awareness (Baer, Smith, and Allen 2004; Baer et al. 2006; Brown and Ryan 2003), non-judgemental acceptance (Baer et al. 2006; Bishop et al. 2004; Brown and Ryan 2003; Lau et al. 2006) and observing (Baer, Smith, and Allen 2004; Baer et al. 2006). Therefore, despite subtle permutations in conceptions of secular mindfulness, they retain a close resemblance to bare attention. Furthermore, in contrast to the multifarious previous uses of mindfulness in both Western and Buddhist contexts, mindfulness is now given neat operational definitions comprised of clearly delineated components.

This oversimplification in meaning has been both a cause and result of a process of 'de-Buddhicisation', in which the Buddhist origins and meanings of mindfulness have been obscured. In the scientific literature, mindfulness is sometimes attributed to Buddhist roots, by means of a passing mention (Zoogman et al. 2014, 1), with no acknowledgement of the ways it may differ from a classical Buddhist understanding of mindfulness. At other times it is attributed to 'Eastern' traditions (Brotto, Krychman, and Jacobson 2008, 2741; Follette, Palm, and Pearson 2006, 45) or 'cultural meditation practices' (Jha, Krompinger, and Baime 
2007, 109). Another strategy is to frame mindfulness as a concept that is found in a wide range of religious and spiritual traditions, as well as Western philosophy and psychology (Harris 2009, 8; Shapiro 2009, 555). Still plenty of publications make no mention of Buddhism at all (Davidson et al. 2003; Greeson 2009; Irving, Dobkin, and Park 2009).

Moving mindfulness even further away from its Buddhist origins in satipatthāna practice, mindfulness, defined in these operational terms, is even being decoupled from meditation. Whereas the classical Buddhist understanding suggests that mindfulness needs to be developed through meditative practice, a key assumption of mindfulness questionnaires is that mindfulness is an inherent capacity that naturally differs between individuals, including non-meditators. Meditation is seen as a helpful, but not necessary or exclusive way of cultivating and enhancing 'trait mindfulness', or one's propensity to be mindful (Brown and Ryan 2004, 246).

These trends will be further elaborated and substantiated in the next section, which suggests that the portrayal of mindfulness as a secular, straightforward technique was essential for the mainstreaming of the concept.

\section{The mainstreaming of mindfulness}

Although the word 'mindfulness' has been around since 1530, secular mindfulness is the only usage that has made a substantial impact. As noted, the concept has now spread across several spheres of society, and enthusiasm for mindfulness has recently peaked (Boyce 2011, xviii). Popular articles such as Time magazine's ‘The Mindful Revolution' (Pickert 2014) indicate that mindfulness has well and truly entered the mainstream as part of the contemporary zeitgeist.

This impact can be illustrated at a quantitative level. Google Ngrams chart the prevalence of particular words or phrases, as a percentage of all words published in books, as 
long as they are found in at least 40 books a year, controlling for the total number of books published in any given year. The first Ngram (Figure 1) shows that the usage of mindfulness began to increase around 1960, with an exponential increase from around 1980. This sharp increase coincides with the introduction of secular mindfulness through MBSR (Kabat-Zinn 1982). The second Ngram (Figure 2) suggests that the increase in mentions of 'mindfulness' is not simply due to increased mentions of 'Buddhism', which had increased steadily from 1830.

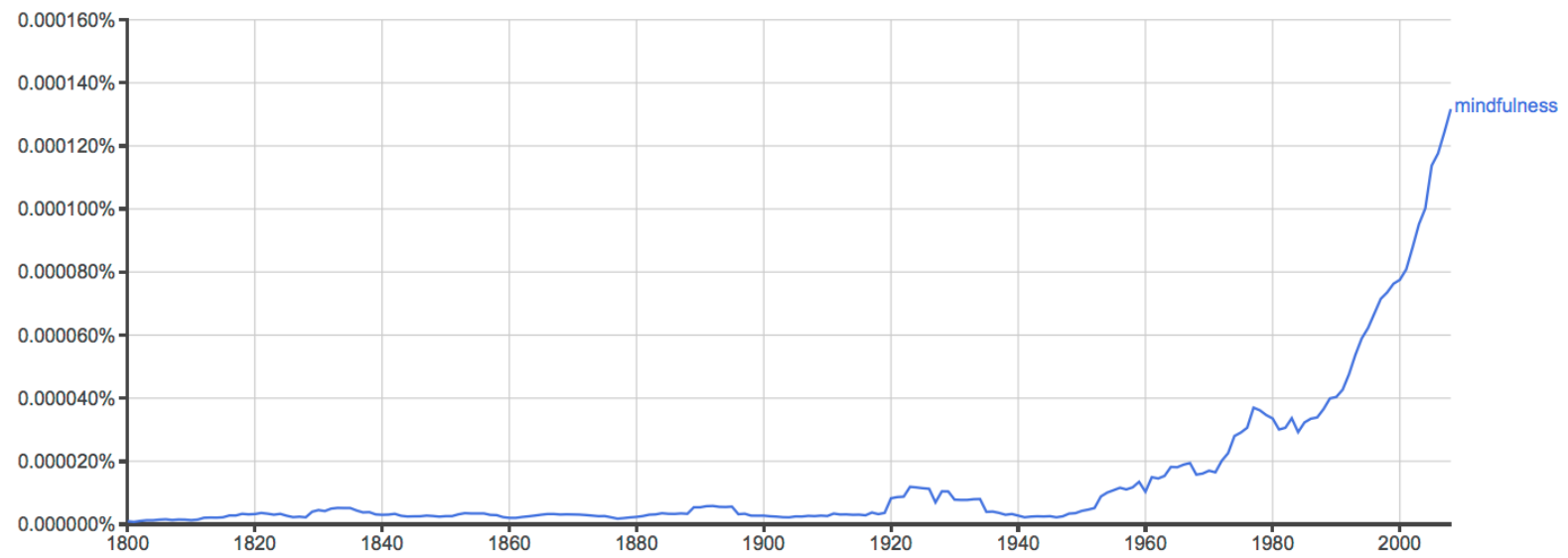

Figure 1. Prevalence of 'mindfulness' in books from 1800

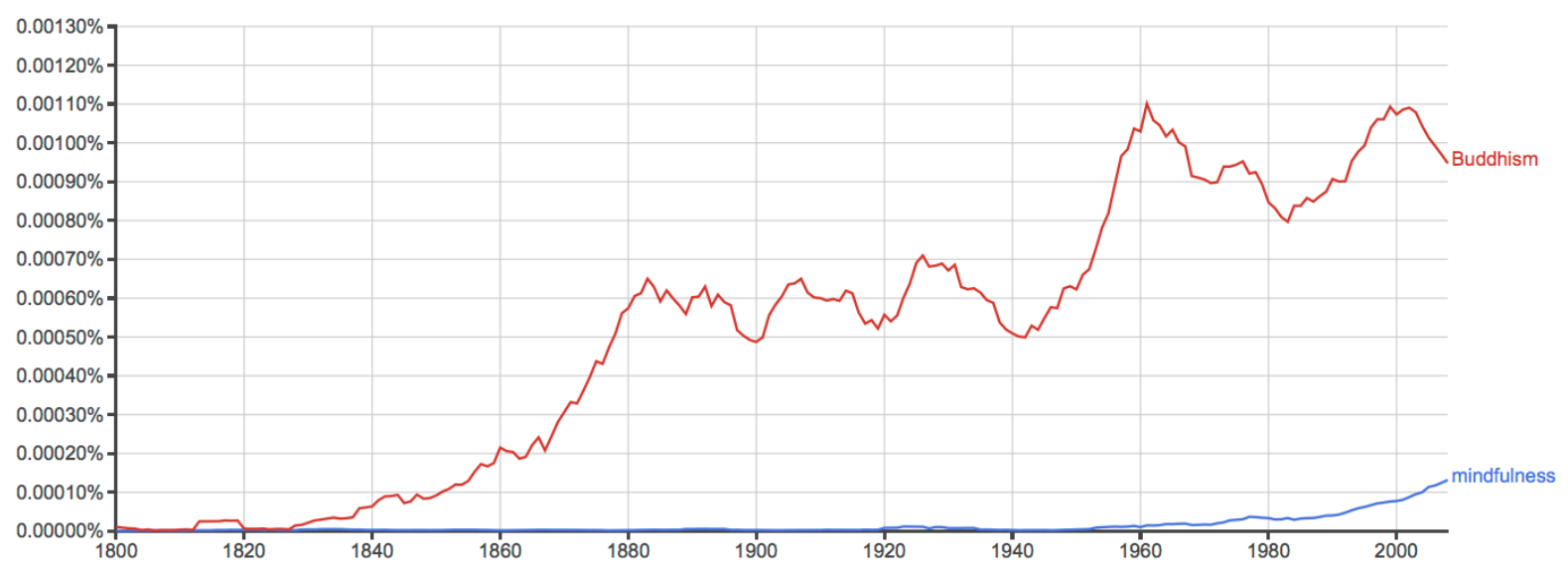

Figure 2. Relative prevalence of 'Buddhism' and 'mindfulness' in books from 1800 
In fact, as discussed in the previous section, and as Figures 3 and 4 suggest, the growth of mindfulness was associated with a 'de-Buddhicisation' of the concept. Figure 3 reveals an exponential increase in publications mentioning 'mindfulness' in the PsycInfo database, with over 2705 scholarly publications corresponding to the search term 'mindfulness' since 2010 alone, compared to fewer than 76 prior to 1990 . This parallels the trend seen in Figure 1. Figure 3 also shows that the gap between mindfulness-only publications and those that have also mentioned 'Buddhism', 'Buddhist' or 'meditation' has widened with time. Figure 4 illustrates this trend as a percentage of mindfulness publications, showing that there has been a general decline in the percentage of mindfulness-related PsycInfo publications that mention Buddhism-related words.

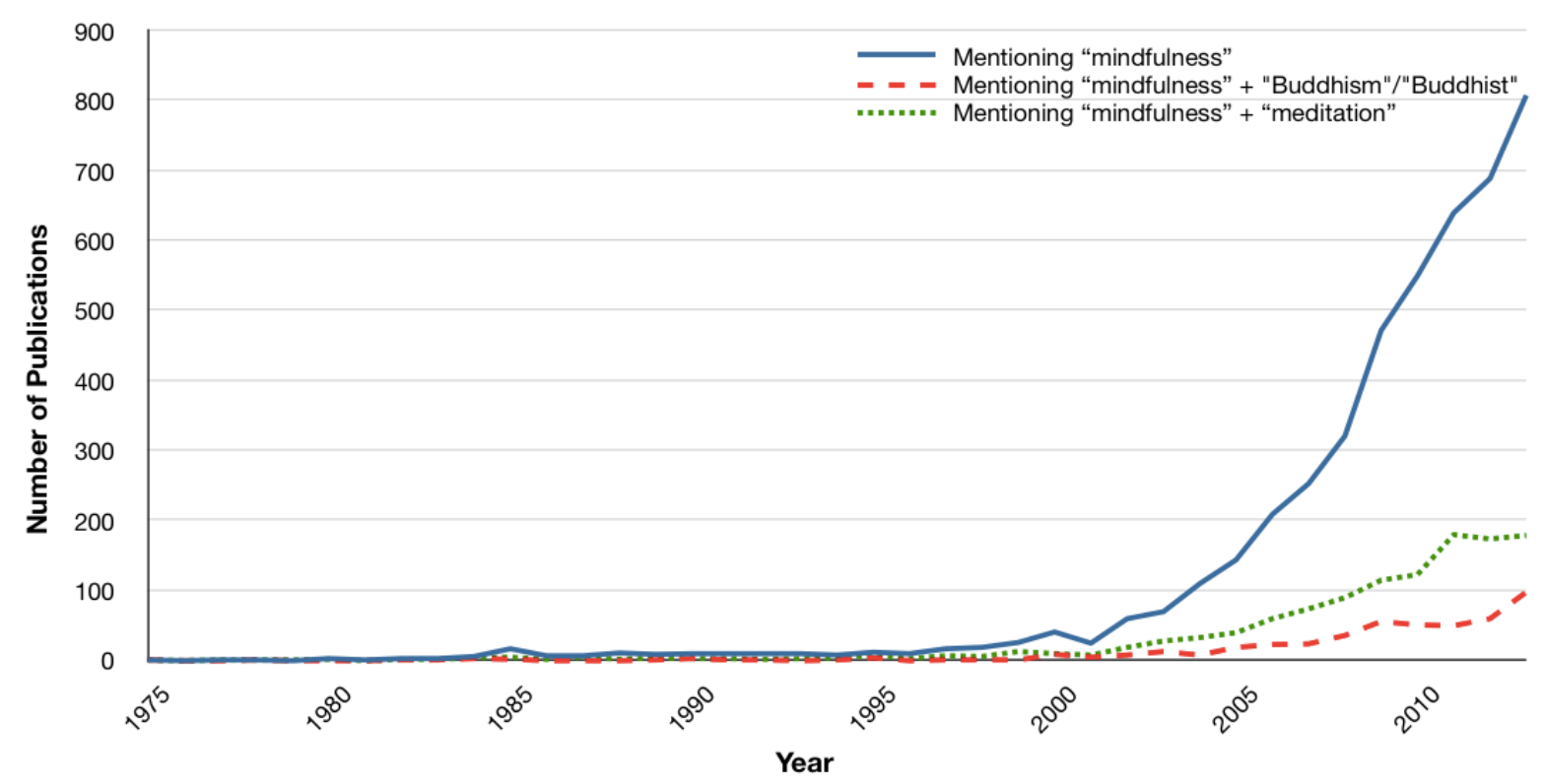

Figure 3. Number of PsycInfo publications mentioning 'mindfulness' alone or with 'Buddhism'/'Buddhist' or 'meditation' 


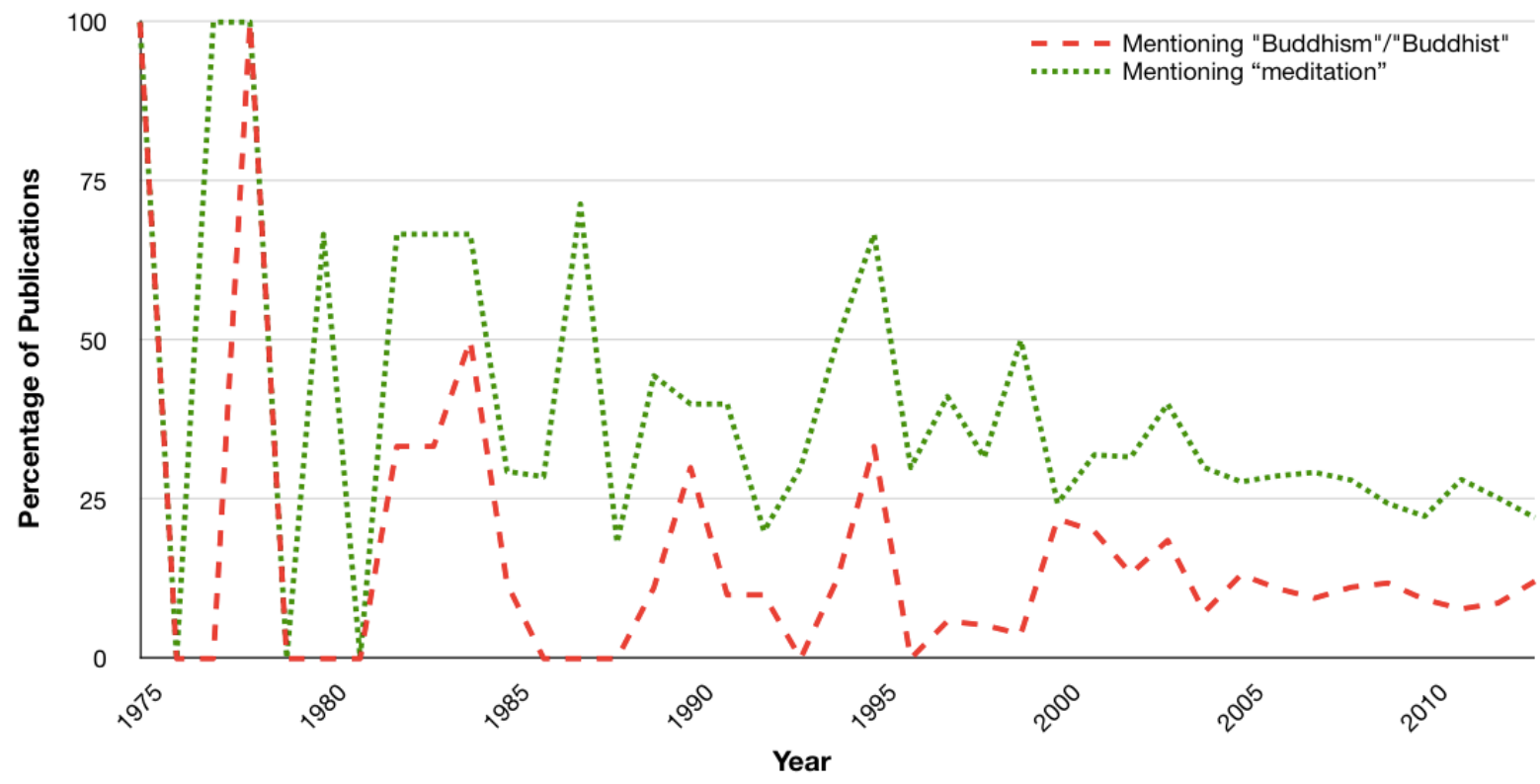

Figure 4. Percentage of PsycInfo publications mentioning 'mindfulness' and 'Buddhism'/ 'Buddhist' or 'meditation'

Overall, these trends suggest that the de-Buddhicisation of mindfulness enabled the concept to enter the mainstream where 'Western' and 'Buddhist' mindfulness failed to make a significant impact. Having established this association, the following sections aim to explain why this approach was so successful.

\section{Secularisation}

It is first instructive to understand Kabat-Zinn's rationale in secularising mindfulness. Kabat-Zinn had extensive training with teachers from various Buddhist traditions, including Seung Sahn (Zen), Jack Kornfield, Joseph Goldstein and Robert Hover (Theravāda/ Vipassanā). He was also influenced by the Soto and Rinzai Zen traditions, Chögyam Trungpa's Meditation in Action, Thich Nhat Hanh's The Miracle of Mindfulness, and the yogic traditions (Kabat-Zinn 2011, 289). However, he actually led the process of de- 
Buddhicisation, often describing his work as an offering of 'the wisdom and the heart of Buddhist meditation without the Buddhism' (Kabat-Zinn 2010).

It began one afternoon, near the end of a two-week vipassana retreat in the Spring of 1979, when Kabat-Zinn had a 'vision' in which it struck him that it would be a worthy work to share the essence of meditation and yoga practices with mainstream Americans who would otherwise never encounter or accept these practices (Kabat-Zinn 2011, 287). He hoped to remove unnecessary barriers for people who were seeking relief from suffering by leaving the 'cultural baggage' behind and developing an 'American vocabulary' to make meditation commonsensical and relatable (Kabat-Zinn 2011, 267-268, 288). This was intended to be a 'skillful means, not the complete Abhidharma' (Kabat- Zinn 2010). Therefore, in MBSR and his landmark book, Full Catastrophe Living (Kabat-Zinn 1990), Kabat-Zinn's vision was to make the Dharma available and accessible to mainstream Americans facing stress, pain and illness, without using the word 'dharma' or appealing to Buddhist thought or authority (Kabat- Zinn 2011, 282).

Kabat-Zinn notes that from the beginning of MBSR, he 'bent over backward' to structure it and find ways to speak about it that avoided the risk of it being seen as 'Buddhist, "New Age", "Eastern Mysticism" or just plain "flakey" (Kabat-Zinn 2011, 282). He saw this as a constant and serious risk that would have undermined attempts to present it as a commonsensical, evidence-based and legitimate element of mainstream medical care (KabatZinn 2011, 282), especially in the late 1970s, when 'virtually everybody in the mainstream thought [meditation] was weird' (Kabat-Zinn 2005, 61). Therefore, Kabat-Zinn chose to describe meditation operationally as the self-regulation of attention, to point out that most of the time, we are barely present in our own bodies and lives, and to give the endeavour the 
umbrella term of 'stress reduction' (Kabat-Zinn 2011, 288). Indeed, MBSR began as the 'Stress Reduction and Relaxation Program' (Kabat-Zinn 2011, 286).

From a clinical and scientific perspective, Shapiro $(2009,555-556)$ echoes the importance of defining mindfulness within a Western psychological context, suggesting that in order for it to be integrated into Western psychology and healthcare, it needs to be translated into a language that clinicians, scientists and scholars can understand and agree on. Baer $(2011,255-256)$ similarly notes the need to define mindfulness in clear psychological terms to facilitate scientific study within psychology, and acknowledges that while secularised understandings of mindfulness within psychology may not capture the nuances of Buddhist teachings, it has made the benefits of mindfulness much more widely available than would otherwise be possible.

The importance of secularisation is further reinforced by the way it has been emphasised in popular media. Congressman Tim Ryan, a passionate proponent of mindfulness at an institutional level, is a Catholic who points out that mindfulness is not a religious practice, but a secular mental technique that can be effective regardless of beliefs (Hruby 2012). Similarly, Jeffery Bearor, the executive deputy of the Marine Corps Training and Education Command comments that mindfulness 'is not tied to any religious practice' but is 'about mental preparation to better handle stress' (Watson 2013). Finally, in The Mindfulness Revolution, Boyce (2011, xii) writes that mindfulness can be practised equally by people of any or no religious faith, as it is based on 'fundamental mental and physical capabilities that all human beings have'.

Overall, this suggests that Kabat-Zinn's approach in secularising mindfulness and advancing an oversimplified, demystified and commonsensical understanding was, and 
continues to be, skilful and essential in facilitating the accessibility and acceptability of the concept to researchers, patients and the general public.

\section{Instrumentalisation}

The secularisation of mindfulness inevitably encouraged a more pragmatic, instrumentalised portrayal, which has further aided its legitimisation and mainstreaming. After all, as Braun $(2013,165)$ notes, when practice is no longer motivated by karmic threat, where the goal for practice is to escape from rebirth, the reasons to practise change radically, towards this-worldly, pragmatic goals. While speculative, it is possible that part of the reason that 'Western' mindfulness became obsolete was that it was not a practical 'technique' and simply lost relevance. Similarly, the traditional Buddhist goal of liberation from the cycle of rebirth was too far removed from the cosmology and goals of a Western audience. The instrumentalisation of secular mindfulness, however, legitimises the practice with here-andnow goals and hard outcomes. This has been especially important in an American culture, which is strongly characterised by pragmatism (Seager 2012, 62; Tori 2006, 319) and is a scientifically informed society (Tori 2006, 319).

The scientific literature on mindfulness is rooted in this instrumental focus, researching how mindfulness can improve outcomes for a variety of ailments, from chronic pain (Kabat-Zinn 1982) to stress, depression, anxiety (Khoury et al. 2013) and eating disorders (Kristeller and Wolever 2010), to name a few. More recently, there has been an increased focus on performance enhancement in non-disordered populations; such findings include improved attention and working memory (Jha, Krompinger, and Baime 2007; Mrazek et al. 2013), increased positive emotion and immune function (Davidson et al. 2003), and even increases in regional grey matter density in the brain (Hölzel et al. 2011). Scientists have also investigated the length and factors required for mindfulness interventions to be effective 
(Carmody and Baer 2009). Research is therefore geared towards optimising the outcomes of mindfulness practice.

In popular books, the subtitle of Tim Ryan's (2012) manifesto, A Mindful Nation, is illustrative: 'How a Simple Practice Can Help Us Reduce Stress, Improve Performance and Recapture the American Spirit.' Similarly, The Mindfulness Revolution (Boyce 2011) is devoted to explaining how mindfulness can enhance enjoyment and effectiveness in daily life, benefit physical and emotional health, and help with relationships. The popular discourse surrounding mindfulness is therefore decidedly perky, portraying mindfulness as a panacea.

More broadly, mindfulness is operating within a context of modernity, characterised by a pervasive calculative rationality oriented towards profit, productivity and efficiency (Dawson and Turnbull 2006, 62). In this context, the discourse of instrumentalisation is made especially salient when mindfulness is talked about in terms of the potential profits and cost savings it could bring. Arianna Huffington (2013) has written that '[ $t$ ]here's nothing touchyfeely about increased profits' and that mindfulness is a 'proven competitive advantage'.

Similarly, Chade-Meng Tan, the founder of Google's mindfulness and emotional intelligence training programme, Search Inside Yourself, notes that mindfulness can help build compassion, which 'can and will be good for success and profits' (Gregoire 2013). From a political standpoint, the prospect of significant cost savings in healthcare makes mindfulness seem particularly compelling (Hruby 2012; McCabe Ruff and Mackenzie 2009).

Overall, popular discourse strongly suggests that mindfulness is only worthy of attention for the practical benefits that it brings as a useful and evidence-based 'skill', 'tool' or 'technique' (Purser and Loy 2013; Seager 2012, 62; Tori 2006, 316). Therefore, instrumentalisation, facilitated by secularisation, has played a critical role in the mainstreaming of mindfulness. 


\section{Mindfulness and Buddhism today}

Now that mindfulness has entered the mainstream, albeit in a different and substantially simplified form, it has sparked new discussion about its relationship with Buddhism. The response from Buddhists has not been entirely enthusiastic, with some criticising the 'dumbing down' of mindfulness. Others, however, are optimistic about its transformative potential. Taking these perspectives and the history of Buddhism into account, I will now consider the implications for Buddhism and the future of mindfulness.

\section{McMindfulness: a denaturing of the practice?}

Critics have suggested that the rush to secularise mindfulness and present it as an isolated technique that serves purely instrumental ends may lead to a denaturing of the practice, coining the term 'McMindfulness' (Neale 2011; Purser and Loy 2013). Purser and Loy (2013) argue that when decontextualised from its original liberative purpose and its foundation in ethics and dissolving the roots of greed, hatred and delusion, mindfulness becomes a banal self-help technique that can reinforce these roots.

Purser and Loy (2013) further note the distinction between Right Mindfulness (sammā-sati) and Wrong Mindfulness (micchā-sati), which depends on whether the quality of awareness is characterised by wholesome intentions. After all, one can 'mindfully' commit a heinous crime. Similarly, Dawson and Turnbull (2006, 61-62) argue that mindfulness does not 'naturally' produce ethical, wise and serene human beings, but depends on the social and cultural contexts it is being taught in. They suggest that it can be easily turned to narcissistic and harmful ends, providing a cautionary tale of the way that meditation enhanced the capacity to kill in the military elite of pre-WWII Japan. These concerns have turned out to be astute, as the US Marine Corps are now in fact using mindfulness to optimise performance during combat (Watson 2013). 
A related criticism is that mindfulness has often been presented as a private, internal affair and marketed as a method for personal fulfilment, thereby reducing it to a rather selfcentred pursuit (Cohen 2010, 112; Purser and Loy 2013). Purser and Loy (2013) argue that this individualistic orientation obscures the interconnectedness of the causes of suffering across society, thereby creating a dissociation between personal transformation and social and organisational transformation.

Even at a practical level, some therapists have suggested that the oversimplification of mindfulness may reduce its clinical utility and potential for lasting change. From this perspective, emphasising the meditative aspect of the threefold training of ethics (silla),

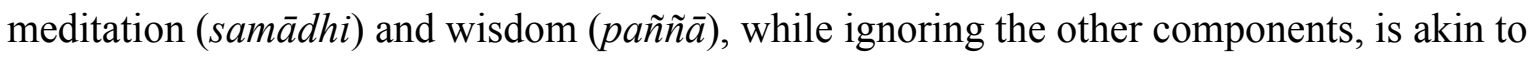
stripping a multi-purpose vehicle of its functioning systems (Huxter 2007, 53). Speaking from clinical experience, Neale $(2011,12)$ suggests that this can only result in temporary states of calm and peace, rather than eliminating the erroneous views that are the roots of afflictive emotions and reactive habits. Similarly, Dawson and Turnbull $(2006,63)$ have found that meditation, without an ethical foundation, can become a dissatisfying and frustrating experience, leading to superficial calmness.

Therefore, critics argue that the oversimplification of mindfulness runs the risk of losing its transformative potential, and that mindfulness can only move beyond a fad or quick fix and become a genuine force for personal and social transformation by reclaiming Buddhist concepts, especially its ethical framework.

\section{Returning to the Dharma?}

At the same time, others have suggested that there is more than what meets the eye with secular mindfulness programmes, which may be embedded within an implicit Dharma framework, especially when created and taught by people with good intentions and a solid 
grounding in traditional mindfulness. Kabat-Zinn $(2011,288)$ has noted that a few weeks into MBSR, many participants exclaim, 'This isn't stress reduction. This is my whole life!' Similarly, Elisha Goldstein (2013) notes that his Mindfulness at Work ${ }^{\mathrm{TM}}$ programme integrates the important qualities of awareness, compassion and the importance of community, and that participants have reported transformations far beyond stress reduction. Even Thich Nhat Hanh believes that as long as business leaders practise 'true' mindfulness, the practice will fundamentally change their perspective on life, even if the original intention was to be more effective at work (Confino 2014). Stress reduction and increased concentration may therefore represent entry points and opportunities for deeper lessons.

Furthermore, Kabat-Zinn $(2011,298)$ suggests that the Dharma can be 'selfrevealing'. Using the framework of 'stress reduction', participants can explore the experience of $d u k k h a$ without using that term, experience craving and clinging, investigate the possibility for alleviating that suffering, and explore a possible pathway for doing so, without explicitly learning about the Four Noble Truths, the Eightfold Noble Path, or sīla, samāadhi, and pañña (Kabat-Zinn 2011, 298). Similarly, without mentioning anicca, practitioners often realise the constantly changing nature of sensations, and therefore, their impermanence (Kabat-Zinn 2011, 299). Finally, instructors can embody loving-kindness, compassion, joy, and equanimity, and introduce ways of cultivating these qualities, without invoking the Four Immeasurables (Kabat-Zinn 2011, 299).

For these reasons, some commentators have suggested that secular mindfulness may represent 'stealth' or 'disguised' Buddhism (Fronsdal 1998, 165; Seager 2012, 212). Looking historically, wherever Buddhism has spread, it has been transformed to incorporate, complement and build on elements of indigenous beliefs, to make it more palatable (Cohen 2010, 106; Fronsdal 1998, 170). Just as the Buddha's own approach was to operate within the 
existing, largely Brahmanical discourse (Bamford 2012, 322), Buddhist practices may now need to appeal to instrumental concerns to be accepted by the average Westerner in the twenty-first century.

After all, can you imagine the reaction if you walked into a corporation, school or clinic and said, 'We have a Buddhist meditation programme that embeds ethical guidelines for the benefit of all beings and aims to liberate you from the cycle of rebirth'? Marketing a programme to meet people where they are is a helpful strategy that can attract people and allow them to have a genuinely beneficial experience that gets them in touch with what matters (Goldstein 2013). In this way, the oversimplification of mindfulness may represent a strategic and necessary scaffolding, a skilful recontextualisation rather than a decontextualisation, which has aided the successful introduction of Buddhist ideas, reframed in a culturally acceptable way.

Considering how this fits into the history of American Buddhism more broadly, the current 'mindfulness movement' may represent a logical continuation of the 'selective fusion of Buddhist worldview and American spirit' (Seager 2012, 63) that has been in progress for over a century. In fact, Seager $(2012,60)$ suggests that the mindfulness movement is currently the most prominent, public face of American Buddhism. Seager (2012, 61-63) characterises this ‘American Buddhist mainstream' as a highly educated, overwhelmingly white group. Tendencies include a reformist, 'back to basics' historical and textual orientation to the Buddha's earliest or 'true' teachings, a socially engaged ethic, and a pragmatic, thisworldly orientation, which they believe to be the main point of the Buddha's teachings, rather than traditional convictions about rebirth.

Characterising and extending this approach, the 'vipassanā movement', growing in the US since the early 1980s, has emphasised meditation as the central practice, often 
presenting it as 'the heart of the Buddhist path' (Fronsdal 1998, 168, 171). It has reformist tendencies and a socially engaged focus in taking 'what the Buddha taught' as a key criterion for authenticity (Braun 2013, 163; Seager 2012, 65) and portraying meditation as a practice that allows one to alleviate suffering and discover freedom 'in the midst of this very world' (Kornfield 1993, x), rather than from cycles of rebirth. Furthermore, proponents of this movement began to separate vipassana meditation from Buddhism by offering the practice outside of its traditional Theravāda Buddhist context. As a result, practitioners were more likely to describe their involvement as 'spiritual' rather than 'religious' (Fronsdal 1998, 169), with Kornfield explaining, 'More and more, we're teaching meditation not as a religious activity but as a support for living a wise and healthy and compassionate inner life' (as quoted in Braun 2013, 166). Even with this pragmatic approach, the traditional Buddhist values of loving-kindness, ethics, and generosity remain important elements in a mindfulness-based spiritual life (Fronsdal 1998, 173).

I would interpret the mindfulness movement as the logical next step of the vipassana movement, with its emphasis on meditation practice, its reformist attitude of leaving the 'cultural baggage' behind, and a solid this-worldly orientation. The mindfulness movement just takes these characteristics to a further extreme, with its exclusive focus on mindfulness, a more explicit emphasis on instrumental benefits, and its ostensible divorce from Buddhism, in which teachings and values have become implicit, if at all present.

In a way, this moves practice beyond Buddhism for many (Braun 2013, 169). This is, after all, the goal that some proponents of secular mindfulness have in mind. Certainly, Kabat-Zinn hoped that MBSR could communicate the Dharma expressed in a universal way, with 'non-attachment to name and form' (Kabat-Zinn 2010). Exemplifying the 'back to basics' approach of reform Buddhists, he explains: 
... going back to the beginning. If it's really all about mindfulness and suffering and the potential to relieve suffering and even the full cessation of suffering ... then if the 'Buddhism' piece of it, which is very highly culturally conditioned, gets in the way, that doesn't serve the purposes of the Four Noble Truths. (Kabat-Zinn 2010)

Of course, Kabat-Zinn's own reformist interpretations and attempts to espouse a more universal, less 'Buddhist' framework are arguably just as 'highly culturally conditioned', which brings up the important question of who exercises cultural authority and has a voice in American Buddhism. As Seager $(2012,71)$ notes, apart from a few prominent teachers, Asian American Buddhists play a marginal role in the Euro-American Buddhist imaginary. Seager $(2012,65)$ suggests that this may create a myopia on the side of Euro-American teachers, who seem to claim normative status for their views and practice as the emergent Western Buddhism (Goldstein 2003). Yet, given the plurality of Buddhist traditions and the lack of a central authority figure, is there really anyone who is uniquely qualified to assert 'what Buddhism is really about'?

A related issue is whether people can legitimately choose to selectively reinterpret and use the Dharma. Bodhi $(2011,36)$, at least, is comfortable with letting people take from the Dharma whatever they find useful, even if it is for secular purposes, if such practices are intended to help others. Furthermore, if the Dharma is understood as the nature of reality, or a set of ideas that can be universally applicable, then perhaps it is not something that Buddhists can 'copyright' and be possessive over. Even so, it would only be decent to tread respectfully on such sacred territory, which must require a basic appreciation for the roots of the practice and the meanings it holds. This has been one of my aims in writing this article. 
Leaving these lingering concerns about cultural imperialism and appropriation aside, I will lastly consider the potential for an increased influence of Buddhist teachings. Will mindfulness, as many believe, move beyond individual stress reduction and transform society? Even while Kabat-Zinn $(2011,281)$ believes that the current momentum signals 'a multi-dimensional emergence of great transformative and liberative promise $\ldots$ which ... may give rise to a flourishing on this planet akin to a second, and this time global, Renaissance', he recognises that this vision depends on whether the investigation and adaptation of mindfulness maintains its full depth, integrity and potential $(2011,285)$. This may be difficult as the new generation of mindfulness teachers may not necessarily have the same original connection to the Dharma (Kabat-Zinn 2010), but there is now a growing conversation about introducing psychologists to Buddhist principles to help them to ground their teaching in the Dharma (Kabat-Zinn 2011; Maex 2011; Teasdale and Chaskalson (Kulananda) 2011).

Once again, Kabat-Zinn is 'bending over backwards', but this time to define the highest level of practical, Dharmic standards possible so that mindfulness does not just become another cognitive-behavioural intervention tool (Kabat-Zinn 2010). It cannot be assumed $a$ priori that secular mindfulness will either be 'denatured' or 'transformative', as extreme critics and optimists have proposed. Instead, taking a more balanced view, it is more likely that the future discourse and impact of mindfulness will continue to be determined by the framework it is taught within and the training and intentions of those who are promoting the practice. Therefore, there continues to be a need for skilful means. Now that mindfulness has become mainstream, however, it has at least opened up the possibility for such conversations to take place. 


\section{Conclusion}

From Godliness to increased profits and liberation to stress reduction, understandings and usages of 'mindfulness' have varied enormously across time and place. Even as the concept has evolved, however, it has depended on previous forms, even if the links are not always made clear. What is clear is that the concept of mindfulness is more compelling and popular than it has ever been. I have proposed that this has been the result of a strategic oversimplification and reframing of mindfulness as a secularised, instrumentalised technique; recontexualised in a culturally relevant and acceptable form. More broadly, this shows that the popularity of an idea depends on the extent to which it resonates with the cultural climate and needs of its contemporaries.

The mainstreaming of mindfulness has, in turn, catalysed more critical and reflective discussions about whether this represents an adaptation of Buddhism itself, and the concerns and promise that this may bring. While warnings and optimistic appraisals of secular mindfulness abound, I have encouraged a more balanced view, suggesting that the long-term impact of mindfulness will depend on how it continues to be nurtured, taught and applied. Only time will reveal whether secular mindfulness will realise its transformative potential, but the door is newly open, ready to welcome the possibility of promising developments. Therefore, I am excited to see how this tentative new discourse will continue to evolve, and in the process, potentially foster more wisdom, compassion and awareness in the world.

\section{Acknowledgements}

I would like to express my deepest gratitude to my advisor, Dr Justin McDaniel, for his invaluable guidance, feedback and kind encouragement throughout the research and writing process. I am humbled and greatly inspired by his generosity. 
References

Alfton, C. F. 1704. Of Private Devotion...In a Method Agreeable to the Liturgy. London: Printed for Rob Clavel and Rob Knaplock.

Ambrose, Isaac. 1652. Media: The Middle Things, in Reference to the First and Last Things. Glasgow: Printed for Archibald Ingram.

Baer, Ruth A. 2011. "Measuring Mindfulness.” Contemporary Buddhism 12 (1): 241-261. doi:10.1080/14639947.2011.564842.

Baer, Ruth A., Gregory T. Smith, and Kristen B. Allen. 2004. “Assessment of Mindfulness by Self-report: The Kentucky Inventory of Mindfulness Skills.” Assessment 11 (3): 191206. doi:10.1177/1073191104268029.

Baer, Ruth A., Gregory T. Smith, Jaclyn Hopkins, Jennifer Krietemeyer, and Leslie Toney. 2006. "Using Self-report Assessment Methods to Explore Facets of Mindfulness.” Assessment 13 (1): 27-45. doi:10.1177/1073191105283504.

Bailey, Nathaniel, and Edward Harwood. 1782. An Universal Etymological English Dictionary. s.v. "mindfulness". London: Printed for T. Osborne.

Bamford, Geoffrey. 2012. "Reform Buddhism \& Clinical Mindfulness: A Study in Cultural Adaptation." Paper presented at the 2nd IABU Conference, Ayutthaya, Thailand.

Berry, Wendell. 1969. The Long-Legged House. Berkeley: Counterpoint.

Bishop, Scott R. S. R., Mark M. Lau, Shauna S. Shapiro, Linda L. Carlson, Nicole D. N. D. Anderson, James J. Carmody, Zindel V. Z. V. Segal, et al. 2004. “Mindfulness: A Proposed Operational Definition." Clinical Psychology: Science and Practice 11 (3): 230-241. doi:10.1093/clipsy/bph077.

Bodhi, Bhikkhu. 2011. "What Does Mindfulness Really Mean? A Canonical Perspective." Contemporary Buddhism 12 (1): 19-39. doi:10.1080/14639947.2011.564813. 
Boyce, Barry, ed. 2011. The Mindfulness Revolution. Boston: Shambhala Publications, Inc.

Braun, Erik. 2013. The Birth of Insight. Chicago: The University of Chicago Press.

Bronte, Charlotte. 1857. "Letters on a First Visit To London." In The Life of Charlotte Bronte, edited by Elizabeth C. Gaskell, 94-95. Oxford: Oxford University Press.

Brotto, Lori A., Michael Krychman, and Pamela Jacobson. 2008. "Eastern Approaches for Enhancing Women's Sexuality: Mindfulness, Acupuncture, and Yoga (CME).” Journal of Sexual Medicine 5 (12): 2741-2748. doi:10.1111/j. 1743-6109.2008.01071.x.

Brown, Kirk W., and Richard M. Ryan. 2003. "The Benefits of Being Present: Mindfulness and Its Role in Psychological Well-being." Journal of Personality and Social Psychology 84 (4): 822-848. doi:10.1037/0022-3514.84.4.822.

Brown, Kirk W., and Richard M. Ryan. 2004. "Perils and Promise in Defining and Measuring Mindfulness: Observations From Experience.” Clinical Psychology: Science and Practice 11 (3): 242-248. doi:10.1093/clipsy/bph078.

Carmody, James, and Ruth A. Baer. 2009. "How Long Does a Mindfulness-based Stress Reduction Program Need to Be? A Review of Class Contact Hours and Effect Sizes for Psychological Distress.” Journal of Clinical Psychology 65 (6): 627-638. doi: 10.1002/jclp.20555.

Cicero, Marcus T. 1841. The Political Works of Marcus Tullius Cicero . . . Translated by Francis Barham. London: Edmund Spettigue.

Cohen, Elliot. 2010. "From the Bodhi Tree, to the Analyst's Couch, then into the MRI Scanner: The Psychologisation of Buddhism." Annual Review of Critical Psychology 8: 97-119. 
Confino, Jo. 2013. “Google Seeks Out Wisdom of Zen Master Thich Nhat Hanh.” The Guardian, September 6. http://www.theguardian.com/sustainable-business/ globaltechnology-ceos-wisdom-zen-master-thich-nhat-hanh

Davidson, Richard J., Jon Kabat-Zinn, Jessica Schumacher, Melissa Rosenkranz, Daniel Muller, Saki F. Santorelli, Ferris Urbanowski, Anne Harrington, Katherine Bonus, and John F. Sheridan. 2003. “Alterations in Brain and Immune Function Produced by Mindfulness Meditation.” Psychosomatic Medicine 65 (4): 564-570. doi: 10.1097/01.PSY.0000077505.67574.E3.

Dawson, Geoff, and Liz Turnbull. 2006. "Is Mindfulness the New Opiate of the Masses? Critical Reflections from a Buddhist Perspective.” Psychotherapy in Australia 12 (4): $60-64$.

Delta. 1830. "The Probationer of Lochievale." The Atheneum or Spirit of the English Magazines 4: 388-394.

Dreyfus, Georges. 2011. “Is Mindfulness Present-centred and Non-judgmental? A Discussion of the Cognitive Dimensions of Mindfulness." Contemporary Buddhism 12 (1): 4154. doi:10.1080/14639947.2011.564815.

Faber, Frederick W. 1855. Growth in Holiness: Or, The Progress of the Spiritual Life. Baltimore: John Murphy Company.

Follette, Victoria, Kathleen M. Palm, and Adria N. Pearson. 2006. "Mindfulness and Trauma: Implications for Treatment.” Journal of Rational-Emotive \& Cognitive-Behavior Therapy 24 (1): 45-61. doi:10.1007/s10942-006-0025-2.

Fronsdal, Gil. 1998. "Insight Meditation in the United States: Life, Liberty, and the Pursuit of Happiness." In The Faces of Buddhism in America, edited by Charles S. Prebish and Kenneth K. Tanaka, 163-180. Berkeley: University of California Press. 
Gethin, Rupert. 2011. “On Some Definitions of Mindfulness.” Contemporary Buddhism 12 (1): 263-279. doi:10.1080/14639947.2011.564843.

Gogerly, Daniel J. 1845. "On Buddhism.” Journal of the Ceylon Branch of the Royal Asiatic Society 1: 7-28.

Goldstein, Joseph. 2003. One Dharma: The Emerging Western Buddhism. New York, NY: HarperCollins Publishers, Inc.

Goldstein, Elisha. 2013. "Beyond McMindfulness: A Thoughtful Reply.” The Blog Huffington Post, July 12. http://www.huffingtonpost.com/elisha-goldstein-phd/ mindfulness_b_3582548.html

Greeson, Jeffrey M. 2009. “Mindfulness Research Update: 2008.” Complementary Health Practice Review 14 (1): 10-18. doi:10.1177/1533210108329862.

Gregoire, Carolyn. 2013. “Google’s 'Jolly Good Fellow' on the Power of Emotional Intelligence." The Huffington Post, September 30. http://www. huffingtonpost.com/ 2013/09/29/googles-jolly-good-fellow_n_3975944.html

Grymeston, Elizabeth. (1604) 1992. "Miscelanea. Meditations. Memoratives.” In English Women's Voices, 1540-1700, edited by Charlotte F. Otten, 290-300. Miami: Florida International University Press.

Gunaratana, Henepola. 2002. Mindfulness in Plain English. Boston: Wisdom Publications. Hamilton, James. 1850. A Memoir of Lady Colquhoun. New York, NY: Carter \& Brothers. Hardy, Robert S. 1850. Eastern Monachism. London: Partridge and Oakey. Harris, Russ. 2009. ACT Made Simple: An Easy-to-Read Primer on Acceptance and Commitment Therapy. Oakland: New Harbinger Publications.

Henry, Matthew. 1790. An Exposition of the Old and New Testament. Vol. 6 Vol. 2. Edinburgh: Printed for Bell and Bradfute, J. Dickson, and J.M. Cliesh. 
Hoyt, Wayland. 1894. “The Prayer-Meeting Service.” The Homiletic Review 28: 358-362.

Hölzel, Britta K., James Carmody, Mark Vangel, Christina Congleton, Sita M. Yerramsetti, Tim Gard, and Sarah W. Lazar. 2011. "Mindfulness Practice Leads to Increases in Regional Brain Gray Matter Density.” Psychiatry Research: Neuroimaging 191 (1): 36-43. doi:10.1016/j.pscychresns.2010.08.006.

Hruby, Patrick. 2012. "Washington Was Making Rep. Tim Ryan Sick . . Until He Found Mindfulness.” The Washington Times, July 11. http://www.washingtontimes.com/ news/2012/jul/11/ohio-democrat-uses-mindfulness-stress-reduction-te

Huffington, Arianna. 2013. "Mindfulness, Meditation, Wellness and Their Connection to Corporate America's Bottom Line.” The Blog - Huffington Post, March 18. http:// www.huffingtonpost.com/arianna-huffington/corporate-wellness_b_2903222. html

Huxter, Malcolm J. 2007. “Mindfulness as Therapy from a Buddhist Perspective.” In Innovations and Advances in Cognitive Behaviour Therapy, edited by D. A. Einstein, 43-55. Bowen Hills: Australian Academic Press.

Irving, Julie A., Patricia L. Dobkin, and Jeeson Park. 2009. "Cultivating Mindfulness in Health Care Professionals: A Review of Empirical Studies of Mindfulness-based Stress Reduction (MBSR)." Complementary Therapies in Clinical Practice 15 (2): 61-66. doi:10.1016/j.ctcp.2009.01.002.

Jha, Amishi, Jason Krompinger, and Michael J. Baime. 2007. "Mindfulness Training Modifies Subsystems of Attention." Cognitive, Affective \& Behavioral Neuroscience 7 (2): 109-119.

Johnson, Samuel. (1755) 1838. A Dictionary of the English Language . . . s.v. “mindfulness.” Heidelberg: Joseph Engelmann. 
Kabat-Zinn, Jon. 1982. “An Outpatient Program in Behavioral Medicine for Chronic Pain

Patients Based on the Practice of Mindfulness Meditation: Theoretical Considerations and Preliminary Results." General Hospital Psychiatry 4 (1): 33-47.

Kabat-Zinn, Jon. 1990. Full Catastrophe Living. New York, NY: Dell.

Kabat-Zinn, Jon. 1994. Wherever You Go, There You Are. New York, NY: Hyperion.

Kabat-Zinn, Jon. 2005. "Bringing Mindfulness to Medicine: An Interview with Jon Kabat-

Zinn.” Interview by Karolyn A. Gazella. Alternative Therapies 11 (3): 56-64.

Kabat-Zinn, Jon. 2010. "Mindfulness and the Cessation of Suffering: An Exclusive New

Interview with Mindfulness Pioneer Jon Kabat-Zinn.” Interview by Danny Fisher.

Lion's Roar, October 7. http://www.lionsroar.com/mindfulness-and-the-cessation-of-

suffering-an-exclusive-new-interview-with-mindfulness-pioneer-jon-kabat-zinn/

Kabat-Zinn, Jon. 2011. "Some Reflections on the Origins of MBSR, Skillful Means, and the

Trouble with Maps.” Contemporary Buddhism 12 (1): 281-306. doi:10.1080/

14639947.2011.564844.

Khoury, Bassam, Tania Lecomte, Guillaume Fortin, Marjolaine Masse, Phillip Therien,

Vanessa Bouchard, Marie-Andrée Chapleau, Karine Paquin, and Stefan G. Hofmann.

2013. "Mindfulness-Based Therapy: A Comprehensive Meta-Analysis.” Clinical

Psychology Review 33 (6): 763-771. doi:10.1016/j.cpr.2013.05.005.

Kornfield, Jack, ed. 1993. Teachings of the Buddha. Boston: Shambhala.

Kristeller, Jean L., and Ruth Q. Wolever. 2010. “Mindfulness-Based Eating Awareness

Training for Treating Binge Eating Disorder: The Conceptual Foundation.” Journal of Eating Disorders 19 (1): 49-61. doi:10.1080/10640266.2011.533605.

Lau, Mark A., Scott R. Bishop, Zindel V. Segal, Tom Buis, Nicole D. Anderson, Linda Carlson, Shauna Shapiro, James Carmody, Susan Abbey, and Gerald Devins. 2006. 
“The Toronto Mindfulness Scale: Development and Validation.” Journal of Clinical Psychology 62 (12): 1445-1467.

Maex, Edel. 2011. "The Buddhist Roots of Mindfulness Training: A Practitioners View." Contemporary Buddhism 12 (1): 165-175. doi:10.1080/14639947.2011.564835. McCabe Ruff, Kelley, and Elizabeth R. Mackenzie. 2009. "The Role of Mindfulness in Healthcare Reform: A Policy Paper.” Explore 5 (6): 313 - 323. doi:10.1016/j.explore. 2009.10.002.

Mrazek, Michael D., Michael S. Franklin, Dawa T. Phillips, Benjamin Baird, and Jonathan W. Schooler. 2013. "Mindfulness Training Improves Working Memory Capacity and GRE Performance While Reducing Mind Wandering.” Psychological Science 24 (5): 776-781. doi:10.1177/0956797612459659.

Neale, Miles. 2011. "McMindfulness and Frozen Yoga: Rediscovering the Essential Teachings of Ethics and Wisdom.” Accessed October 29, 2014. http://www. milesneale.com/wp-content/uploads/2011/11/McMindfulness.pdf

Nisbet, James. 1856. "The Stars and the Promises.” The Quarterly Journal of Prophecy 8: $378-387$.

Nyanaponika, Thera. 1962. The Heart of Buddhist Meditation. London: Riders.

O., H.. 1737. "Letters to the Author." The Gentleman's Magazine, and Historical Chronicle 7: 335.

Palsgrave, John. 1530. L'éclaircissement de La Langue Française. Paris: Imprimerie Nationale.

Perry, William, and Samuel Johnson. 1805. The Synonymous, Etymological, and Pronouncing English Dictionary. s.v. “mindfulness.” London: Printed for John Walker. 
Pickert, Kate. 2014. “The Mindful Revolution.” Time Magazine, January 23. http://time.com/ 1556/the-mindful-revolution

Purser, Ron, and David Loy. 2013. "Beyond McMindfulness.” The Blog - Huffington Post, July 1. http://www.huffingtonpost.com/ron-purser/beyond-momindfulness_b_ 3519289.html

Raleigh, Mary G. 1883. Alexander Raleigh, Records of His Life. Edinburgh: A\&C Black. Rhys Davids, Thomas W. 1881. Buddhist Suttas. Oxford: Clarendon Press.

Rhys Davids, Thomas W. (1890) 2001. The Questions of King Milinda. Vol. 1. London: Curzon.

Rhys Davids, Thomas W. 1910. Dialogues of the Buddha. Vol. 2. London: Henry Frowde. Roesart, A. 1859. "Home Whispers.” The Advocate and Family Guardian 25: 60. Ryan, Tim. 2012. A Mindful Nation: How a Simple Practice Can Help Us Reduce Stress, Improve Performance, and Recapture the American Spirit. USA: Hay House.

Seager, Richard H. 2012. Buddhism in America. 2nd ed. New York, NY: Columbia University Press.

Shapiro, Shauna. 2009. “The Integration of Mindfulness and Psychology.” Journal of Clinical Psychology 65 (6): 555-560. doi:10.1002/jclp.20602.

Shaw, John B. 1907. “The Prayer-Meeting.” The Homiletic Review 54: 361-362.

Shaw, Sarah. 2008. Introduction to Buddhist Meditation. New York, NY: Routledge.

Sutton, Christopher. 1630. Godly Meditations Upon the Most Holy Sacrament of the Lord's Supper. New York, NY: Appleton.

Teasdale, John D., and Michael Chaskalson (Kulananda). 2011. "How Does Mindfulness Transform Suffering? I: The Nature and Origins of Dukkha." Contemporary Buddhism 12 (1): 89-102. doi:10.1080/14639947.2011.564824. 
Tori, Christopher D. 2006. "Buddhism in America: The Primacy of Meditative Practice." In Buddhist Thought and Applied Psychological Research: Transcending the Boundaries, edited by Dinesh K. Nauriyal, Michael S. Drummond, and Y. B. Lal, 314-340. New York, NY: Routledge.

Watson, Julie. 2013. "Marine Corps Studying How Mindfulness Meditation Can Benefit Troops." The Huffington Post, January 22. http://www.huffingtonpost.com/ 2013/01/22/marine-corps-mindfulness-meditation_n_2526244.html

Webster, Noah. 1914. Webster's Elementary-school Dictionary. s.v. “mindfulness.” New York, NY: American Book Company.

Zoogman, Sarah, Simon B. Goldberg, William T. Hoyt, and Lisa Miller. 2014. "Mindfulness Interventions with Youth: A Meta-Analysis.” Mindfulness January 2014: 1-13. doi: 10.1007/s 12671-013-0260-4. 